\title{
Penerapan Metode Role Playing untuk Meningkatkan Aktivitas Belajar dan Prestasi Belajar Siswa pada Mata Pelajaran Fiqih di Mtsn Rarangjami Tasikmalaya
}

\author{
H e r t i k a ${ }^{1 *}$ \\ 1 Kemeterian Agama Tasikmalaya
}

Keywords:

Metode Role Playing, Aktivitas Belajar, Prestasi Belajar, Mata Pelajaran Fiqih

*Correspondence Address: hertika1999@gmail.com
Abstract: The learning of Fiqh in MTsN Rarangjami Tasikmalaya is still dominated by lecture or expository methods. This method does not develop students' critical thinking skills to solve a problem around them and does not motivate them to play an have such an active role in the learning process, so that the quality of learning is low and student's learning achievement is also low. One of the ways to overcome the problems mentioned above is the application of Role Playing method in learning Fiqh. Considering the fact above, this research aims to investigate the application of Role Playing method as a way to improve student learning activities and student achievement. The focus of this research is student learning activities and student achievement. This study also aims to determine the increase in student learning activities and student learning outcomes by using the Role Playing method. This research is a classroom action research consisting of 2 cycles with 4 times face-to-face, with the subject of the study at class IX A students of MTsN Rarangjami Tasikmalaya, amounting to 40 people. Quantitative data analysis was carried out descriptively by using learning completeness techniques and categorization techniques, and qualitative data, functioning as supportive data, were analyzed through the stages of data reduction, data exposure, and the conclusion of the analysis results. The results of this study indicate that the application of the Role Playing method successfully increases learning activities and student achievement in Fiqh Subjects at MTsN Rarangjami Tasikmalaya. This indicator of success can be seen from the increase in the student's learning activities classically from $62 \%$ in the first cycle to $82 \%$ in the second cycle, and an increase in mastery learning from $72.5 \%$ in the first cycle to $95 \%$ in the second cycle

Abstract: Pembelajaran Fiqih di MTsN Rarangjami Tasikmalaya selama ini masih didominasi oleh metode ceramah atau ekspositori, sehingga kualitas pembelajaran dan prestasi belajar siswa juga rendah. Salah satu cara untuk mengatasi masalah tersebut adalah penerapan metode Role Playing. Mengingat hal tersebut, penulis mencoba meneliti tentang penerapan metode Role Playing sebagai salah satu cara untuk meningkatkan aktivitas belajar dan prestasi belajar siswa. Penelitian ini bertujuan untuk mengetahui peningkatan aktivitas belajar dan hasil belajar siswa dengan menggunakan metode Role Playing. Penelitian ini merupakan penelitian tindakan kelas yang terdiri atas 2 siklus dengan 4 kali tatap muka, dengan subjek penelitian adalah siswa kelas IX A MTsN Rarangjami Tasikmalaya yang berjumlah 40 orang. Analisis data kuantitatif dilakukan secara deskriptif dengan teknik ketuntasan belajar dan teknik kategorisasi, dan data kualitatif yang merupakan data pendukung dianalisis melalui tahapan reduksi data, pemaparan data, dan penyimpulan hasil analisis. Hasil penelitian ini menunjukkan penerapan metode Role 
Playing behasil meningkatkan aktivitas belajar dan prestasi belajar siswa pada Mata Pelajaran Fiqih di MTsN Rarangjami Tasikmalaya. Indikator keberhasilan ini terlihat dari adanya peningkatan aktivitas belajar siswa secara klasikal dari $62 \%$ pada siklus I menjadi $82 \%$ pada siklus II, dan peningkatan ketuntasan belajar dari $72,5 \%$ pada siklus I menjadi $95 \%$ pada siklus II.

\section{Pendahuluan}

Penetapan standar proses pendidikan merupakan kebijakan yang sangat penting dan strategis untuk pemerataan dan peningkatan kualitas pendidikan. Melalui standar proses pendidikan setiap guru dapat menentukan bagaimana seharusnya proses pembelajaran berlangsung. Peningkatkan kualitas pembelajaran dapat dimulai dari menganalisis setiap komponen yang dapat membentuk dan mempengaruhi proses pembelajaran. Komponen yang selama ini dianggap mempengaruhi proses pendidikan adalah komponen guru. Bagaimanapun bagus dan idealnya kurikulum pendidikan, serta lengkapnya sarana dan prasarana pendidikan, tanpa diimbangi dengan kemampuan guru dalam menerapkannya, maka semuanya akan sia-sia. ${ }^{1}$

Seorang guru idealnya membekali diri dengan keterampilan dan kemampuan memilih strategi dan metode pembelajaran yang sesuai dengan tujuan kurikulum. Hal ini didasari oleh anggapan bahwa ketepatan dalam memilih metode dan menggunakan berbagai macam model strategi pembelajaran akan berpengaruh terhadap hasil belajar siswa. Guru dalam pembelajaran juga harus dapat memanfaatkan sarana dan prasarana yang menunjang pembelajaran agar tujuan yang diinginkan dapat tercapai.

\footnotetext{
1 Nana Sudjana, Dasar-Dasar Proses Belajar Mengajar, Bandung: Sinar Baru Algesindo, 2005
}

Mengungkapkan bahwa kehadiran guru dalam proses pembelajaran memegang peranan sangat penting yaitu sebagai sutradara sekaligus aktor, artinya pada gurulah tugas dan tanggung jawab merencanakan dan melaksanakan pengajaran di sekolah. ${ }^{2}$ Tugas guru tidak hanya sekedar menyampaikan materi pelajaran kepada siswa (transfer of knowledge), namun juga melaksanakan pembelajaran. Belajar merupakan proses perubahan tingkah laku dengan serangkaian kegiatan yang memiliki beberapa tujuan yaitu mengetahui suatu kepandaian, kecakapan yang sebelumnya tidak pernah diketahui, dapat mengerjakan sesuatu yang sebelumnya tidak dapat dikerjakan dan dapat menerapkan pengetahuan yang diperoleh.

Metode sangat berfungsi dalam menyampaikan materi pelajaran. Perlu juga menjadi pertimbangan bahwa ada materi yang berkenaan dengan dimensi afektif dan psikomotorik, dan ada materi yang berkenaan dengan dimensi kognitif, yang kesemuanya itu menghendaki pendekatan metode yang berbeda-beda. Proses pembelajaran meliputi kegiatan memilih, menetapkan, mengembangkan metode untuk mencapai hasil pembelajaran yang diinginkan. Pemilihan, penetapan dan pengembangan metode didasarkan pada kondisi pembelajaran yang ada. Kegiatan-kegiatan

2 Nana Sujdjana dan Ibrahim, Penelitian Kualitatif dan Penelitian Kuantitatif, Bandung: Sinar Baru, 1989 
tersebut pada dasarnya merupakan inti dari perencanaan pembelajaran. ${ }^{3}$

Ketika penentuan suatu metode pembelajaran, guru terlebih dahulu memahami tujuan, jenis dan sifat materi pelajaran yang akan disampaikan. Karena dengan kemampuan guru dalam memahami tujuan dan jenis materi pelajaran dapat menetapkan metode pembelajaran yang sesuai. Metode pembelajaran yang diterapkan oleh guru untuk materi pelajaran yang berupa fakta/konsep akan berbeda dengan metode pembelajaran yang berisi tentang suatu prosedur begitu pula sebaliknya.

Pendidikan dan pengajaran kita pada masa ini masih berpusat pada guru, sehingga aktivitas siswa dalam pembelajaran masih rendah, sebagaimana yang dikatakan Nurhadi bahwa "kegiatan pendidikan saat ini masih didominasi oleh pandangan: (1) pengetahuan sebagai rangkaian fakta-fakta yang harus dihafal, (2) kelas masih terfokus pada guru sebagai sumber utama ilmu pengetahuan, dan (3) ceramah menjadi pilihan utama strategi pembelajaran". 4

Menurut Munandar dalam Nashori dan Diana menunjukkan bahwa "ada kecenderungan kreatifitas tidak dapat berkembang secara optimal di kalangan subjek didik Indonesia yang mayoritas beragama Islam". Hal ini disebabkan karena pendidikan formal di Indonesia terlalu menekankan pemikiran-pemikiran yang bersifat konvergen yaitu kemampuan untuk memberikan jawaban satu-satunya yang tepat sebagaimana diajarkan guru.

Siswa jarang dirangsang untuk melihat satu persoalan dari berbagai sudut yang berbeda. Pemikiran yang bersifat divergen (memberikan alternatif jawaban yang bermacam-macam terhadap suatu persoalan) jarang tersentuh, sehingga siswa menjadi kaku, kurang terbuka dan toleran terhadap pandangan yang berbeda. Sesuatu yang baru dan berbeda sering tidak disukai dan ditolak. Mereka merasa lebih aman terhadap hal-hal yang sudah ada, lama atau konvensional.

Paulo Freir telah mengkritik sistem pendidikan seperti ini, dengan menyebutnya sebagai metode gaya banking, di mana hubungan antara guru dengan siswa, masih bersifat subjek dan objek. Siswa lebih menyerupai bejanabejana kosong yang siap dituangkan air (ilmu) oleh gurunya. Siswa sebagai celengan dan guru sebagai penabung. 5 Unsur kreatifitas, diskusi, bermain peran, masih menjadi barang langka dalam proses pembelajaran. Guru sebagai ujung tombak dalam pendidikan menempatkan dirinya sebagai orang yang serba tahu dan paling mengetahui.

Kondisi tersebut makin diperparah dengan masih diandalkannya metode pembelajaran yang lebih menitik beratkan pada sistem hafalan, proses pembelajaran hanya berkutat dalam persoalan menghafal definisi, konsep-konsep, teori dan sebagainya sehingga tidak banyak ruang gerak bagi siswa untuk melahirkan konsep dan ide sendiri.

Setelah ditelusuri, pembelajaran Fiqih di MTsN Rarangjami Indihiang Kota Tasikmalaya mengalami beberapa kendala antara lain: materi pelajaran Fiqih begitu banyak dan padat sedangkan waktu yang disediakan sangat terbatas yaitu 2 jam pelajaran dalam satu minggu, padahal pembelajaran Fiqih tidak hanya sekedar menghafal sejumlah konsep, pemahaman

\footnotetext{
3 Undang-Undang No. 20 tahun 2003 tentang Sistem Pendidikana Nasional

and Learning/CTL) dan Penerapannya, Malang: Penerbit Universitas Negeri Malang, 2003

4 Nurhadi dan Agus Gerrad Senduk, Pembelajaran Kontekstual (Contextual Teaching Yogyakarta: Graha Ilmu, 2007
} 
dan penghayatan terhadap konsepkonsep tersebut akan tetapi lebih dari itu yaitu berpikir kreatif, analisis dan kritis sehingga pelajaran lebih bermakna. Minimnya berbagai sarana atau media pembelajaran, metode dan strategi yang digunakan dalam pembelajaran tidak variatif, metode konvensional yaitu ceramah lebih sering digunakan, sehingga mematikan kreatifitas, berpikir kritis dan analisis siswa. Kendala-kendala tersebut di atas menyebabkan aktivitas belajar dan prestasi belajar siswa dalam Pembelajaran fiqih di MTsN Rarangjami Tasikmalaya masih rendah dan kurang memuaskan.

Berdasarkan permasalahan di atas, maka peneliti ingin mengadakan upaya perbaikan untuk menyelesaikan masalah yang ada melalui penelitian tindakan kelas, dalam rangka menyelasikan atau mengatasi masalah aktivitas belajar siswa dan prestasi belajar siswa yang masih rendah tersebut, akan diterapkan metode Role Playing dalam pembelajaran Fiqih di MTsN Rarangjami Tasikmalaya.

\section{Kajian Teori Aktivitas Belajar}

Menurut Echols dan Shadily, aktivitas berasal dari bahasa Inggris activity yang berarti kegiatan. ${ }^{6}$ Sedangkan belajar adalah perubahan tingkah laku yang relatif mantap berkat latihan dan pengalaman. ${ }^{7}$ Dengan demikian yang dimaksud aktivitas belajar adalah kegiatan yang dilakukan baik fisik maupun mental untuk memperoleh perubahan tingkah laku.

Inti proses pembelajaran adalah kegiatan belajar siswa dalam mencapai suatu tujuan pembelajaran. Tujuan pembelajaran tentu saja akan dapat tercapai jika siswa berusaha secara aktif untuk mencapainya. Keaktifan siswa di sini tidak hanya dituntut dari segi fisik, tetapi juga dari segi kejiwaan. Bila hanya fisik siswa yang aktif, tetapi pikiran dan mentalnya kurang aktif, maka kemungkinan besar tujuan pembelajaran tidak tercapai. Ini sama artinya siswa tidak belajar, karena siswa tidak merasakan perubahan di dalam dirinya. Padahal belajar pada hakikatnya adalah "perubahan" yang terjadi di dalam diri seseorang setelah berakhirnya melakukan aktivitas belajar.

Hamalik dengan meringkas pendapat dari Dierdrich membagi aktivitas kegiatan belajar dalam 8 kelompok, ialah:

a. Kegiatan-kegiatan visual, meliputi; membaca, mengamati gambargambar, eksperimen, demonstrasi, pameran, dan orang lain bekerja atau bermain.

b. Kegiatan-kegiatan lisan, meliputi; mengemukakan suatu fakta atau prinsip, menghubungkan kejadian, mengajukan pertanyaan, memberi saran, mengemukakan pendapat, wawancara, diskusi, dan interupsi.

c. Kegiatan-kegiatan mendengarkan, meliputi; mendengarkan penyajian bahan, percakapan atau diskusi, suatu permainan, dan radio.

d. Kegiatan-kegiatan menulis, meliputi; menulis cerita, laporan, karangan, membuat rangkuman, mengerjakan tes, dan mengisi angket.

e. Kegiatan-kegiatan menggambar, meliputi; menggambar, membuat grafik, diagram, peta, dan pola.

f. Kegiatan-kegiatan metrik, meliputi; melakukan percobaan, memilih alatalat, melaksanakan pameran, membuat model, menyelenggarakan permainan, menari, dan berkebun.

7 Oemar Hamalik, Proses Belajar Mengajar, Jakarta: PT. Bumi Aksara, 2007 
g. Kegiatan-kegiatan mental, meliputi; merenungkan, mengingat, memecahkan masalah, menganalisis, melihat dukungan, dan membuat keputusan.

h. Kegiatan-kegiatan emosional, meliputi; menaruh minat, membedakan, berani, tenang, dan lain-lain. ${ }^{8}$

Berdasarkan pendapat di atas, aktivitas belajar yang dilakukan oleh siswa di sekolah dapat digolongkan dalam 3 golongan, yaitu:

a. Aktivitas Mental, adalah aktivitas yang bercirikan intelektual dan emosional yang meliputi; menanggap, mengingat, memecahkan soal, menganalisis, melihat hubungan dan mengambil keputusan.

b. Aktivitas Fisik, kegiatan ini antara lain meliputi; mendengarkan, melihat, menulis, membaca, berbicara atau berbentuk perbuatan lain sehingga memungkinkan pengalaman belajar yang diperoleh lebih baik.

c. Aktivitas Sosial, meliputi hubungan siswa dengan guru, hubungan siswa dengan siswa lain, sikap kooperatif atau kerja sama, tolong menolong, berdiskusi, dan lain sebagainya.

\section{Prestasi Belajar}

Menurut Suryabrata, prestasi belajar adalah nilai sebagai rumusan yang diberikan guru bidang studi mengenai kemajuan belajar selama masa tertentu. ${ }^{9}$ Menurut Tu'u, prestasi belajar adalah pencapaian siswa dalam mengerjakan tugas atau kegiatan pembelajaran

8 Oemar Hamalik, Perencanaan Pengajaran Berdasarkan Pendekatan Sistem, Jakarta: Bumi Aksara, 2003

9 Sumadi Suryabrata, Psikologi Pendidikan, Jakarta: Raja Grafindo Persada, 1998

10 Tulus Tu'u, Peran Disiplin pada Perilaku dan Prestasi Peserta Didik, Jakarta: Grasindo, 2004 melalui penguasaan pengetahuan atau keterampilan mata pelajaran yang ditunjukkan dengan nilai tes atau angka nilai yang diberikan oleh guru. ${ }^{10}$

Menurut Sudjana, prestasi belajar adalah hasil yang telah dicapai seseorang dalam melakukan proses untuk mendapatkan perubahan tingkah laku kognitif, afektif, dan psikomotorik.11 Sedangkan, Tohirin menyatakan bahwa prestasi belajar adalah apa yang telah dicapai oleh siswa setelah melakukan kegiatan belajar. ${ }^{12}$

Berdasarkan beberapa pendapat tersebut, maka dapat disimpulkan bahwa prestasi belajar adalah hasil yang dicapai atau ditunjukkan oleh siswa sebagai hasil belajarnya yang diperoleh melalui pengalaman dan latihan. Hal ini bisa merupakan angka, huruf, serta tindakan yang dicapai masing-masing anak dalam waktu tertentu.

Untuk lebih konkritnya dapat dijelaskan sebagai berikut: (1) Prestasi belajar adalah hasil belajar yang dicapai oleh siswa ketika mengikuti dan mengerjakan tugas pembelajaran di sekolah; (2) Prestasi belajar adalah pencapaian nilai mata pelajaran tertentu berdasarkan kemampuan siswa dalam aspek pengetahuan, ingatan, aplikasi, analisis, sintesis, dan evaluasi; (3) Prestasi belajar adalah nilai yang dicapai oleh siswa melalui ulangan atau ujian yang diberikan oleh guru.

\section{Metode Role Playing}

Metode role playing adalah sejenis permainan gerak yang di dalamnya ada tujuan, aturan dan sekaligus melibatkan

\footnotetext{
11 Nana Sudjana, Dasar-Dasar Proses Belajar Mengajar, Bandung: Sinar Baru Algesindo, 2005 12 Tohirin, Psikologi Pembelajaran Pendidikan Agama Islam, Jakarta: Rajagrafindo Persada, 2006
} 
unsur senang. Penerapan metode role playing mengkondisikan siswa pada situasi tertentu di luar kelas, meskipun saat itu pembelajaran terjadi di dalam kelas. Selain itu, role playing seringkali dimaksudkan sebagai suatu bentuk aktivitas dimana pembelajar membayangkan dirinya seolah-olah berada di luar kelas dan memainkan peran orang lain.

Metode role playing memperlakukan siswa sebagai subyek pembelajaran, secara aktif melakukan praktik bermain peran sesuai dengan materi pelajaran yang sedang dipelajari bersama temantemannya pada situasi tertentu. Belajar efektif dimulai dari lingkungan yang berpusat pada diri siswa.

Siswa akan berhasil dalam pembelajaran jika mereka diberi kesempatan mengalami dan mempraktikan apa yang sedang mereka pelajari. Bila mereka berpartisipasi, mereka akan lebih mudah menguasai apa yang mereka pelajari. Jadi, dalam pembelajaran siswa harus aktif. Tanpa adanya aktivitas, maka proses pembelajaran tidak mungkin terjadi.

Pembelajaran dengan model role playing dilaksanakan menjadi beberapa tahap, yaitu sebagai berikut: (1) tahap memotivasi kelompok; (2) memilih pemeran; (3) menyiapkan pengamat; (4) menyiapkan tahap-tahap permainan peran; (5) pemeranan; (6) diskusi dan evaluasi; (7) pemeranan ulang; (8) diskusi dan evaluasi kedua; (9) membagi pengalaman dan menarik generalisasi.

Beberapa langkah yang dilakukan guru dalam menerapkan metode role playing adalah sebagai berikut.

1. Guru menetapkan topik, seperti konflik interpersonal, konflik antar golongan, perbedaan pendapat/ perspektif, dan lain-lain.

2. Guru menunjuk dua orang siswa maju ke depan untuk memerankan karakter tertentu dalam waktu 10-15 menit.

3. Guru meminta kedua siswa tersebut untuk melakukan peran.

4. Pada saat kedua siswa memerankan karakter tertentu di muka kelas, siswa lainnya diminta untuk mengamati dan menuliskan tanggapan mereka.

5. Guru melakukan kesimpulan, klarifikasi, dan tindak lanjut.

\section{Pembelajaran Fiqih dengan Metode Role Playing}

Mata pelajaran Fiqih dalam kurikulum Madrasah Tsanawiyah adalah bagian dari mata pelajaraan Pendidikan Agama Islam. ${ }^{13}$ Pembelajarannya diarahkan untuk menyiapkan siswa untuk mengenal, memahami, menghayati dan mengamalkan hukum Islam, yang kemudian menjadi dasar pandangan hidupnya (way of life) melalui kegiatan bimbingan, pengajaran, latihan, penggunaan pengalaman, pembiasaan dan keteladanan

Materi Fiqih bukan sekedar sejumlah materi yang harus dihafal, akan tetapi dalam kenyataannya materi Fiqih banyak yang berhubungan dengan masalah sosial. Terutama Fiqih mu'amalah yang selalu berkembang seiring dengan perkembangan zaman sehingga dalam pembelajarannya membutuhkan pendekatan dan metode yang memberi peluang untuk usaha penyelidikan, pemikiran lebih mendalam sehingga siswa dibekali cara memecahkan masalah yang dihadapinya

\footnotetext{
13 Dirjen Bagais, Standar Kompetensi Kurikulum 2004 Madrasah Tsanawiyah, Jakarta: Depag RI, 2005
} 
di masyarakat berdasarkan hukum Islam yang benar.

Contoh materi mata pelajaran Fiqih di Madrasah Tsanawiyah yang berhubungan dengan masalah sosial tersebut adalah: jual beli, khiyar, muzāra'ah dan mukhābarah. Materi jual beli misalnya, sering kita jumpai di masyarakat adanya buah-buahan yang menurut kebiasaan baru bisa dimanfaatkan kalau sudah matang tetapi diperjual belikan ketika buah tersebut masih berupa cikal buah atau masih muda seperti buah durian yang masih muda. Apakah hal tersebut sesuai dengan hukum Islam dan bagaimana seharusnya jual beli itu dilakukan? Tentunya akan sangat menarik kalau materi ini diajarkan dengan metode Role Playing. Sehingga anak tertantang untuk mengembangkan kemampuan berpikirnya, tidak hanya menerima informasi dari guru.

\section{METODE PENELITIAN}

Jenis penelitian yang digunakan adalah Penelitian Tindakan Kelas (PTK) atau Classroom Action Research (CAR), yang dilakukan untuk memperbaiki berbagai persoalan nyata dan praktis dalam peningkatan mutu pembelajaran di kelas yang dialami langsung dalam interaksi antara guru dengan siswa yang sedang belajar. ${ }^{14}$

Mekanisme kerja penelitian ini diwujudkan dalam bentuk siklus (direncanakan 2 siklus), yang setiap siklusnya tercakup 4 kegiatan, yaitu (1) perencanaan, (2) pelaksanaan, (3) observasi dan interpretasi, dan (4) analisis dan refleksi.

\footnotetext{
14 Suharsimi Arikunto, et.al, Penelitian Tindakan Kelas, Jakarta: Bumi Aksara, 2007

15 Yatim Riyanto, Metode Penelitian Tindakan, Surabaya: Penerbit SIC, 2001, 96
}

Subjek penelitian ini adalah siswa kelas VIII MTsN Rarangjami Indihiang Kota Tasikmalaya, yang berjumlah 120 orang. Adapun sampelnya sebanyak 40 orang dengan perincian siswa laki-laki sebanyak 16 orang, dan siswa perempuan berjumlah 24 orang. Objek penelitian adalah pembelajaran mata pelajaran Fiqih kelas VIII MTsN Rarangjami Indihiang Kota Tasikmalaya khususnya pembelajaran materi jual beli, khiyar, muzār'ah dan mukhābarah serta hikmahnya.

Jenis Instrumen yang digunakan oleh peneliti sebagai alat pengumpul data pada penelitian ini adalah:

1. Observasi

Observasi merupakan metode pengumpulan data dengan cara melakukan pengamatan terhadap objek penelitian. ${ }^{15}$ Metode observasi ini diharapkan dapat mengetahui kondisi riil yang terjadi di lapangan dan mampu menangkap kenyataan sebanyak mungkin mengenai apa yang terjadi. Metode observasi ini peneliti gunakan untuk mendapatkan gambaran tentang aktivitas belajar siswa dan pengelolaan pembelajaran.

\section{Tes}

Tes adalah alat ukur yang diberikan kepada individu untuk mendapatkan jawaban-jawaban yang diharapkan, baik secara tertulis atau secara lisan atau perbuatan. ${ }^{16}$

Instrumen penelitian memenuhi syarat sebagai alat pengumpul data apabila instrumen penelitian tersebut valid dan reliabel. Uji validitas instrumen bertujuan untuk mengetahui validitas dan reliabilitas serta tingkat kesesuian instrumen penelitian dengan

\footnotetext{
16 Suharsimi Arikunto, Dasar-dasar Evaluasi
}

Pendidikan, Jakarta: PT Bumi Aksara, 2002, 127 
tujuan dan isi materi pembelajaran. Uji validitas, reliabilitas, daya beda soal dan tingkat kesukaran soal dilakukan dengan mengujicobakan soal kepada para siswa di luar subjek yakni siswa kelas IXA MTsN Rarangjami Tasikmalaya untuk soal siklus I dan kelas IX C untuk soal siklus II.

Hasil uji coba soal kemudian dianalisis untuk mengetahui validitas, reliabilitas, tingkat kesukaran, dan daya beda soal. Sedangkan instrumen penelitian yang berupa lembar observasi telah dikonsultasikan sebelumnya kepada guru mata pelajaran Fiqih dan BK sekolah tempat peneliti melakukan penelitian sebagai dasar validitas konstruk.

1. Validitas Butir Soal

Hasil perhitungan tes uji coba soal tes siklus I dengan jumlah soal 25 soal dengan taraf signifikansi 0,05 dan dk 38 diperoleh $r_{\text {tabel }}$ sebesar 0,31 sedang jumlah soal untuk soal tes siklus II sebanyak 25 soal dengan taraf signifikansi 0,05 dan dk 37 diperoleh rtabel sebesar 0,32. Hasil analisis yang telah dilakukan diperoleh 23 soal yang valid pada soal tes siklus I dan dapat dilihat pada table berikut.

Tabel 1

Rangkuman Validitas Uji Coba Soal Siklus I

\begin{tabular}{|c|c|c|c|}
\hline No & Kriteria & Nomor soal & Jumlah \\
\hline 1 & Valid & $\begin{array}{l}1,2,3,4,5,6,7, \\
8,9,10,12,13, \\
14,16,17,18, \\
19,20,21,22, \\
23,24,25\end{array}$ & 23 \\
\hline \multirow[t]{2}{*}{2} & $\begin{array}{l}\text { Tidak } \\
\text { valid }\end{array}$ & 11,15 & 2 \\
\hline & & & 25 \\
\hline
\end{tabular}

Pada soal tes siklus II diperoleh 21 soal yang valid seperti tabel berikut.

Tabel 2

Rangkuman Validitas Uji Coba Soal Siklus II

\begin{tabular}{|c|c|c|c|}
\hline No & Kriteria & Nomor soal & Jumlah \\
\hline 1 & Valid & $\begin{array}{l}1,2,3,4,5,6,7, \\
8,9,10,11,12,\end{array}$ & 22 \\
& & 8 \\
\hline
\end{tabular}

\begin{tabular}{|c|l|l|c|}
\hline & & $\begin{array}{l}13,14,15,16,17, \\
18,19,21,22,25\end{array}$ & \\
\hline 2 & $\begin{array}{l}\text { Tidak } \\
\text { valid }\end{array}$ & $20,23,24$ & 3 \\
\hline & & & 25 \\
\hline
\end{tabular}

\section{Reliabilitas Soal}

Berdasarkan hasil analisis uji coba soal yang telah dilakukan dengan menggunakan KR-20 diperoleh $\mathrm{r}_{11}$ sebesar 0,92 dengan kriteria sangat tinggi untuk soal siklus I dan $\mathrm{r}_{11}$ sebesar 0,74 dengan kriteri tinggi untuk soal siklus II.

3. Tingkat Kesukaran Soal

Berdasarkan hasil analisis uji coba pada soal tes siklus I diketahui banyak soal dengan kriteria sukar 20\%, dan sedang $80 \%$. Data ini dapat dilihat pada tabel berikut.

Tabel 3.

Rangkuman Tingkat Kesukaran Soal Siklus I

\begin{tabular}{|c|l|c|c|}
\hline No & Kriteria & Jumlah & Prosentasi \\
\hline 1 & Terlalu sukar & 0 & $0 \%$ \\
\hline 2 & Sukar & 5 & $20 \%$ \\
\hline 3 & Sedang & 20 & $80 \%$ \\
\hline 4 & Mudah & 0 & $0 \%$ \\
\hline 5 & Terlalu mudah & 0 & $0 \%$ \\
\hline \multicolumn{2}{|c|}{ Jumlah } & 25 & $100 \%$ \\
\hline
\end{tabular}

Pada soal siklus II diperoleh soal dengan kriteria sukar 8\%, sedang 88\%, dan mudah $4 \%$. Data ini terangkum dalam tabel berikut.

Tabel 4

Rangkuman Tingkat Kesukaran Soal Siklus II

\begin{tabular}{|c|l|c|c|}
\hline No & Kriteria & Jumlah & Prosentasi \\
\hline 1 & Terlalu sukar & 0 & $0 \%$ \\
\hline 2 & Sukar & 2 & $8 \%$ \\
\hline 3 & Sedang & 22 & $88 \%$ \\
\hline 4 & Mudah & 1 & $4 \%$ \\
\hline 5 & Terlalu mudah & 0 & 0 \\
\hline \multicolumn{2}{|c|}{ Jumlah } & 25 & $100 \%$ \\
\hline
\end{tabular}

\section{Daya Pembeda Soal}

Berdasarkan hasil analisis uji coba soal siklus I diketahui banyak soal dengan kriteria daya pembeda jelek 4\%, cukup $4 \%$, baik $36 \%$, dan sangat baik $56 \%$. Dapat dilihat pada tabel berikut. 
Tabel 5

Rangkuman Daya Pembeda Soal Siklus I

\begin{tabular}{|c|c|c|c|}
\hline No & Kriteria & Jumlah & Prosentase \\
\hline 1 & Sangat jelek & 1 & $4 \%$ \\
\hline 2 & Jelek & 0 & $0 \%$ \\
\hline 3 & Cukup & 1 & $4 \%$ \\
\hline 4 & Baik & 9 & $36 \%$ \\
\hline 5 & Baik sekali & 14 & $56 \%$ \\
\hline \multicolumn{2}{|r|}{ Jumlah } & 25 & $100 \%$ \\
\hline
\end{tabular}

Pada soal siklus II diperoleh hasil banyak soal dengan kriteria jelek 4\%, cukup $12 \%$, baik $76 \%$, dan baik sekali 8\%. Dapat dilihat pada tabel berikut.

Tabel 6

Rangkuman Daya Pembeda Soal Siklus II

\begin{tabular}{|c|l|c|c|}
\hline No & Kriteria & Jumlah & Prosentase \\
\hline 1 & Sangat jelek & 0 & $0 \%$ \\
\hline 2 & Jelek & 1 & $4 \%$ \\
\hline 3 & Cukup & 3 & $12 \%$ \\
\hline 4 & Baik & 19 & $76 \%$ \\
\hline 5 & Baik sekali & 2 & $8 \%$ \\
\hline \multicolumn{2}{|c|}{ Jumlah } & 25 & $100 \%$ \\
\hline
\end{tabular}

Berdasarkan hasil analisis dari seluruh soal uji coba, maka pada soal siklus I jumlah soal yang memenuhi kriteria ada 23 soal karena ada dua soal yang tidak valid dan daya bedanya sangat jelek (yakni soal no 11 tidak valid dan no 15 tidak valid dan daya bedanya sangat jelek).

Pada soal siklus II yang memenuhi kriteria dan layak digunakan sebagai instrumen tes ada 22 soal, soal no 20, 23 tidak valid dan no 24 tidak valid serta daya bedanya jelek.

Dalam hal ini peneliti mengambil 20 soal dari masing-masing soal siklus yang telah diuji cobakan tersebut yang memenuhi kelayakan untuk dijadikan instrumen tes dalam penelitian ini.
Data yang diteliti dalam penelitian ini adalah data tentang aktivitas belajar siswa digali melalui observasi dan data tentang prestasi belajar siswa yang digali melalui tes. Data hasil penelitian yang tergolong data kuantitatif dianalisis secara deskriptif yakni dengan menghitung ketuntasan klasikal dan ketuntasan individual didasarkan pada indikator yang telah dirumuskan.

Siswa yang memperoleh nilai kurang dari 65 dinyatakan tidak tuntas dan siswa yang memperoleh nilai lebih dari atau sama dengan 65 dinyatakan tuntas belajar. Ketuntasan belajar klasikal tercapai apabila prosentasi siswa yang tuntas belajar jumlahnya lebih besar atau sama dengan $85 \%$ dari jumlah seluruh siswa di kelas.

Ketuntasan klasikal aktivitas belajar siswa adalah bilamana aktivitas belajar siswa secara klasikal $\geq 80 \%$. Aspek yang dijadikan parameter aktivitas belajar siswa adalah; Siswa bertanya kepada guru, hadir tepat waktu, memperhatikan keterangan guru, memperhatikan informasi yang disampaikan teman, mencatat hal-hal yang relevan dengan materi pembelajaran, aktif dalam diskusi kelompok, aktif dalam diskusi kelas, menjaga ketenangan dalam mengikuti pembelajaran, antusias dalam mengikuti pembelajaran, membuat rangkuman hasil pembelajaran. Aspekaspek ini di skor secara klasikal.

Pada setiap akhir siklus diadakan refleksi tentang hasil tes hasil belajar dan hasil pengamatan dari pembelajaran yang sudah berlangsung. Hasil refleksi ini kemudian dijadikan dasar untuk merencanakan dan pelaksanaan tindakan pada siklus berikutnya.

HASIL PENELITIAN

Aktivitas Belajar Siswa 
Selama pembelajaran berlangsung observasi terhadap aktivitas belajar siswa dilakukan secara kolaboratif antara peneliti dengan pengamat. Adapun hasil observasi pada siklus I mengenai aktivitas siswa ini dapat dilihat pada tabel berikut.

Tabel 7

Aktivitas Belajar Siswa Siklus I

\begin{tabular}{|c|l|c|}
\hline No & \multicolumn{1}{|c|}{ Parameter Aktivitas Siswa } & Skor \\
\hline 1 & Siswa bertanya kepada guru & 3 \\
\hline 2 & Siswa yang hadir tepat waktu & 4 \\
\hline 3 & $\begin{array}{l}\text { Siswa memperhatikan } \\
\text { keterangan guru }\end{array}$ & 4 \\
\hline 4 & $\begin{array}{l}\text { Siswa memperhatikan informasi } \\
\text { yang disampaikan teman }\end{array}$ & 3 \\
\hline 5 & $\begin{array}{l}\text { Siswa mencatat hal-hal yang } \\
\text { relevan dengan materi } \\
\text { pembelajaran }\end{array}$ & 3 \\
\hline 6 & $\begin{array}{l}\text { Siswa aktif dalam diskusi } \\
\text { kelompok }\end{array}$ & 3 \\
\hline 7 & Siswa aktif dalam diskusi kelas & 2 \\
\hline 8 & $\begin{array}{l}\text { Siswa menjaga ketenangan } \\
\text { dalam mengikuti pembelajaran }\end{array}$ & 3 \\
\hline 9 & $\begin{array}{l}\text { Siswa antusias dalam mengikuti } \\
\text { pembelajaran }\end{array}$ & 3 \\
\hline 10 & $\begin{array}{l}\text { Siswa membuat rangkuman } \\
\text { hasil pembelajaran }\end{array}$ & 31 \\
\hline & Jumlah skor \\
\hline & Prosentasi & \\
\hline
\end{tabular}

Kriteria penilaian :

$$
\begin{array}{ll}
80 \%-100 \% & =\text { sangat baik } \\
70 \%-79 \% & =\text { baik } \\
60 \%-69 \% & =\text { cukup } \\
<59 \% & =\text { kurang. }
\end{array}
$$

Dari data tabel tersebut tentang aktivitas belajar siswa siklus I dapat diketahui bahwa aktivitas siswa pada siklus I hanya $62 \%$ ini berada pada ketegori cukup dan masih perlu ditingkatkan lagi pada siklus berikutnya karena tidak memenuhi target minimal yang diharapkan yaitu $80 \%$.

Data aktivitas siwa ini dijadikan pertimbangan untuk tindakan siklus II, yakni perlu adanya upaya peningkatan aktivitas belajar siswa.
Sedangkan hasil observasi mengenai aktivitas belajar siswa pada siklus II dapat dilihat pada tabel berikut.
Tabel 8

Aktivitas Belajar Siswa Siklus II

\begin{tabular}{|c|l|c|}
\hline No & \multicolumn{1}{|c|}{ Parameter aktivitas siswa } & skor \\
\hline 1 & Siswa bertanya kepada guru & 4 \\
\hline 2 & Siswa yang hadir tepat waktu & 5 \\
\hline 3 & $\begin{array}{l}\text { Siswa memperhatikan } \\
\text { keterangan guru }\end{array}$ & 4 \\
\hline 4 & $\begin{array}{l}\text { Siswa memperhatikan informasi } \\
\text { yang disampaikan teman }\end{array}$ & 4 \\
\hline 5 & $\begin{array}{l}\text { Siswa mencatat hal-hal yang } \\
\text { relevan dengan materi } \\
\text { pembelajaran }\end{array}$ & 5 \\
\hline 6 & $\begin{array}{l}\text { Siswa aktif dalam diskusi } \\
\text { kelompok }\end{array}$ & 5 \\
\hline 7 & Siswa aktif dalam diskusi kelas & 4 \\
\hline 8 & $\begin{array}{l}\text { Siswa menjaga ketenangan dalam } \\
\text { mengikuti pembelajaran }\end{array}$ & 4 \\
\hline 9 & $\begin{array}{l}\text { Siswa antusias dalam mengikuti } \\
\text { pembelajaran }\end{array}$ & 4 \\
\hline 10 & $\begin{array}{l}\text { Siswa membuat rangkuman hasil } \\
\text { pembelajaran }\end{array}$ & 4 \\
\hline & Jumlah skor & 43 \\
\hline & Prosentasi \\
\hline
\end{tabular}

Kriteria penilaian :

$$
\begin{array}{ll}
80 \%-100 \% & =\text { sangat baik } \\
70 \%-79 \% & =\text { baik } \\
60 \%-69 \% & =\text { cukup } \\
<59 \% & =\text { kurang }
\end{array}
$$

Tabel tersebut memperlihatkan bahwa aktivitas belajar siswa mengalami peningkatan dari aktivitas belajar siswa siklus I yang hanya $62 \%$ menjadi $86 \%$ pada siklus II. Pada siklus II ini aktivitas belajar siswa berada dalam kategori sangat baik dan sudah melampaui batas minimal aktivitas belajar siswa yang diharapkan yaitu 80\%. Ini berarti aktivitas belajar siswa sudah mencapai indikator keberhasilan tindakan. 


\section{Hasil Belajar/Prestasi Belajar Siswa}

Pada akhir setiap siklus diadakan tes untuk mengukur hasil/prestasi belajar yang dicapai oleh siswa setelah diterapkan metode Role Playing dalam pembelajaran Fiqih. Adapun hasil belajar/prestasi belajar siswa pada siklus I dapat dilihat pada tabel berikut.

Tabel 9

Rangkuman Hasil Belajar Siswa Siklus I

\begin{tabular}{|c|l|c|}
\hline No & \multicolumn{1}{|c|}{ Keterangan } & Perolehan \\
\hline 1 & Nilai terendah & 50 \\
\hline 2 & Nilai tertinggi & 90 \\
\hline 3 & Nilai rata-rata kelas & 6,84 \\
\hline 4 & $\begin{array}{l}\text { Jumlah siswa yang belum } \\
\text { tuntas belajar }\end{array}$ & 11 \\
\hline 5 & $\begin{array}{l}\text { Jumlah siswa yang tuntas } \\
\text { belajar }\end{array}$ & 29 \\
\hline 6 & $\begin{array}{l}\text { Prosentasi ketuntasan } \\
\text { klasikal }\end{array}$ & $72,5 \%$ \\
\hline
\end{tabular}

Berdasarkan temuan yang tercantum dalam tabel 10 diketahui bahwa siswa yang mencapai ketuntasan individu ada 29 orang (memperoleh nilai lebih dari atau sama dengan 65), dan siswa yang belum mencapai nilai ketuntasan individu ada 11 (tidak mencapai nilai 65), rata-rata kelas hasil belajar siswa adalah 6,84 dan ketuntasan klasikal adalah $72.5 \%$.

Sedangkan hasil belajar/prestasi belajar siswa pada siklus II dapat dilihat pada tabel berikut.

Tabel 10

Rangkuman Hasil Belajar Siswa Siklus II

\begin{tabular}{|c|l|c|}
\hline No & \multicolumn{1}{|c|}{ Keterangan } & Perolehan \\
\hline 1 & Nilai terendah & 60 \\
\hline 2 & Nilai tertinggi & 95 \\
\hline 3 & Nilai rata-rata kelas & 7,84 \\
\hline 4 & $\begin{array}{l}\text { Jumlah siswa yang belum } \\
\text { tuntas belajar }\end{array}$ & 2 \\
\hline 5 & $\begin{array}{l}\text { Jumlah siswa yang tuntas } \\
\text { belajar }\end{array}$ & 38 \\
\hline 6 & $\begin{array}{l}\text { Prosentasi ketuntasan } \\
\text { klasikal }\end{array}$ & $95 \%$ \\
\hline
\end{tabular}

Berdasarkan temuan yang tercantum dalam tabel 11 diketahui bahwa siswa yang mencapai nilai ketuntasan individu yakni $\geq 65$ ada 38 orang dan yang tidak mencapai ketuntasan individu ada 2 orang, sedangkan rata-rata kelas hasil belajar siswa adalah 7,84, dan ketuntasan klasikal adalah 95\%.

\section{PEMBAHASAN \\ Aktivitas Belajar Siswa}

Keberhasilan aktivitas belajar siswa diukur berdasarkan aktivitas siswa secara kla-sikal. Peningkatan aktivitas siswa dikatakan berhasil apabila aktivitas belajar klasikalnya $\geq 80 \%$ (aktivitas belajar siswa lebih besar atau sama dengan $80 \%$ ).

Pada siklus I aktivitas belajar siswa selama proses pembelajaran masih belum men-capai harapan yang ditargetkan yaitu aktivitas belajar siswa secara klasikal sebesar 80\%. Aktivitas siswa pada siklus I sebesar hanya $62 \%$ masih dalam kategori cukup dan belum menunjukkan peningkatan yang diinginkan terutama jumlah siswa yang berani bertanya maupun mengunkapkan ide atau gagasannya dalam diskusi kelas masih sedikit. Ini karena siswa belum terbiasa dengan metode pembelajaran aktif (Role Playing) mereka sudah terbiasa hanya menerima informasi dari guru dalam pembelajaran sebelumnya.

Pada siklus II aktivitas siswa mengalami peningkatan yang sangat berarti. Nilai aktivitas siswa secara klasikal telah mencapai 86\%. Ini berarti indikator keberhasilan aktivitas siswa telah tercapai yaitu aktivitas belajar siswa secara klasikal sebesar 80\%. Keberhasilan ini didorong oleh pengelolaan pembelajaran yang dilakukan oleh peneliti/bertindak 
sebagai guru yang selalu memberikan dorongan kepada siswa untuk aktif dalam proses pembelajaran dan pengelolaan pembelajaran yang diterapkan memberikan peluang bagi siswa untuk berperan lebih aktif dalam proses pembelajaran tersebut. Keberhasilan ini juga didorong oleh sikap siswa yang sudah menyenangi atau merespon secara positif terhadap metode yang digunakan dalam pembelajaran Fiqih.

Peningkatan aktivitas siswa tersebut dapat dilihat pada tabel berikut.

Tabel 11

Peningkatan Aktivitas Belajar Siklus I s/d II

\begin{tabular}{|c|l|c|c|}
\hline \multirow{2}{*}{ No } & \multicolumn{1}{|c|}{$\begin{array}{l}\text { Parameter Aktivitas } \\
\text { Siswa }\end{array}$} & $\begin{array}{c}\text { Siklus } \\
\text { I }\end{array}$ & $\begin{array}{c}\text { Siklus } \\
\text { II }\end{array}$ \\
\hline 1 & $\begin{array}{l}\text { Siswa bertanya kepada } \\
\text { guru }\end{array}$ & 3 & 4 \\
\hline 2 & $\begin{array}{l}\text { Siswa yang hadir tepat } \\
\text { waktu }\end{array}$ & 4 & 5 \\
\hline 3 & $\begin{array}{l}\text { Siswa memperhatikan } \\
\text { keterangan guru }\end{array}$ & 4 & 4 \\
\hline 4 & $\begin{array}{l}\text { Siswa memperhatikan } \\
\text { informasi yang } \\
\text { disampaikan teman }\end{array}$ & 3 & 4 \\
\hline 5 & $\begin{array}{l}\text { Siswa mencatat hal-hal } \\
\text { yang relevan dengan } \\
\text { materi pembelajaran }\end{array}$ & 3 & 5 \\
\hline 6 & $\begin{array}{l}\text { Siswa aktif dalam } \\
\text { diskusi kelompok }\end{array}$ & 3 & 5 \\
\hline 7 & $\begin{array}{l}\text { Siswa aktif dalam } \\
\text { diskusi kelas }\end{array}$ & 2 & 4 \\
\hline 8 & $\begin{array}{l}\text { Siswa menjaga } \\
\text { ketenangan dalam } \\
\text { mengikuti pembelajaran }\end{array}$ & 3 & 4 \\
\hline 9 & $\begin{array}{l}\text { Siswa antusias dalam } \\
\text { mengikuti pembelajaran }\end{array}$ & $\begin{array}{l}\text { Jumlah skor } \\
\text { rangkuman hasil }\end{array}$ & 43 \\
\hline 10 & $\begin{array}{l}\text { Siswa membuat } \\
\text { pembelajaran }\end{array}$ & $86 \%$ \\
\hline & $\begin{array}{l}\text { Prosentasi } \\
\text { nong }\end{array}$ & 4 \\
\hline
\end{tabular}

\section{Hasil Belajar/Prestasi Belajar Siswa}

Hasil belajar siswa dilihat dari hasil observasi awal dan tes akhir baik pada siklus I maupun siklus II. Optimalisasi hasil belajar siswa berupa hasil tes akhir diukur dari ketercapaian ketuntasan individual dan ketuntasan klasikal.

Berdasarkan data yang diperoleh dari hasil belajar siklus I, sebagai gambaran ketuntasan klasikal dan individual pembelajaran dengan menggunakan metode Role Playing yang diukur melalui tes akhir, maka diketahui hasil tes akhir siklus I belum mencapai ketuntasan klasikal. Dimana pada siklus I ketuntasan klasikal hasil tes akhir hanya sebesar 72,5\% atau hanya 29 orang siswa yang mencapai ketuntasan individual. Hasil post test tersebut belum sesuai dengan indikator ketuntasan klasikal yang diitetapkan yaitu $\geq 85 \%$. Namun demikian hasil ini telah menunjukkan peningkatan dari hasil belajar observasi awal yaitu 37,5\% (hanya 15 orang siswa yang mencapai ketuntasan individual.

Hal tersebut disebabkan karena siswa belum terbiasa belajar dengan metode pemecahan masalah (Role Playing) dimana mereka melakukan penyelidikan sendiri dan mencari sendiri pemecahan masalah terhadap masalah yang ditemukan sebagai alat untuk memahami materi pembelajaran Fiqih. Djamarah dan Aswan menyatakan "mengubah kebiasan siswa belajar dengan mendengarkan dan menerima informasi dari guru menjadi belajar dengan banyak berpikir memecahkan permasalahan sendiri atau kelompok, yang kadangkadang memerlukan berbagai sumber belajar merupakan kesulitan tersendiri bagi siswa".

Kurang optimalnya hasil belajar siswa pada siklus I disebabkan juga peneliti yang bertindak sebagai guru belum dapat mengkondisikan kelas dengan baik yang ditunjukkan dengan masih banyaknya siswa yang ramai sendiri selama proses pembelajaran, dan terdapat siswa yang nampak bosan 
selama kegiatan pembelajaran berlangsung.

Hasil ini perlu ditindak lanjuti dengan melanjutkan pembelajaran Fiqih menggunakan metode Role Playing pada kegiatan pembelajaran siklus II untuk membiasakan siswa belajar dengan metode Role Playing, dan lebih memotivasi siswa agar aktif dalam proses pembelajaran.

Hasil belajar yang telah dicapai pada siklus II menunjukkan adanya peningkatan dari siklus I dimana pada siklus I ketuntasan klasikal hanya 72,5\%, pada siklus II ketuntasan klasikal telah mencapai angka 95\% dimana ada 38 siswa yang mencapai ketuntasan individual. Ini berarti hasil siklus II telah mencapai indikator keberhasilan tindakan yaitu ketuntasan klasikal sebesar $85 \%$.

Tabel 12

Peningkatan Prestasi Belajar Siklus I s/d II

\begin{tabular}{|c|c|c|c|c|}
\hline \multirow[b]{2}{*}{ No } & \multirow{2}{*}{ Keterangan } & \multicolumn{3}{|c|}{ Perolehan } \\
\hline & & 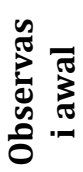 & 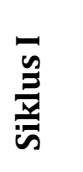 & 品 \\
\hline 1 & Nilai terendah & 35 & 50 & 60 \\
\hline 2 & Nilai tertinggi & 85 & 90 & 95 \\
\hline 3 & Rata-rata kelas & 6,1 & 6,84 & 7,84 \\
\hline 4 & $\begin{array}{l}\text { Jumlah siswa yang } \\
\text { belum tuntas }\end{array}$ & 25 & 11 & 2 \\
\hline 5 & $\begin{array}{l}\text { Jumlah siswa yang } \\
\text { sudah tuntas }\end{array}$ & 15 & 29 & 38 \\
\hline 6 & $\begin{array}{l}\text { Prosentasi } \\
\text { ketuntasan klasikal }\end{array}$ & $37 \%$ & $72 \%$ & $95 \%$ \\
\hline
\end{tabular}

Hal ini tidak terlepas dari kemampuan siswa dalam mengikuti pola pembelajaran dengan menggunakan metode Role Playing dengan baik, di samping itu kemampuan peneliti (bertindak sebagai pengajar) dalam mengelola kelas juga mendukung keberhasilan dalam pembelajaran. Pengajar harus mampu untuk menyusun kegiatan belajar yang mendorong siswa menjadi aktif, berorientasi pada tujuan dan juga proses serta sesuai dengan siklus belajar.

Pembelajaran Fiqih dengan menggunakan metode Role Playing dilakukan dalam kaidah mengajak siswa langsung kepermasalahan yang terjadi di lingkungan atau membawa permasalah yang terjadi di lingkungan ke dalam kelas sebagai sumber belajar untuk mempelajari dan memecahkan permasalahan tersebut. Djamarah dan Aswan mengatakan "mencari data atau keterangan yang dapat digunakan untuk memecahkan masalah dapat dilakukan misalnya dengan membaca buku, meneliti, bertanya, berdiskusi, dan lainlain. Dengan kata lain pengetahuan yang selama ini didapatkan hanya melalui teori dapat diperoleh siswa secara langsung melalui pembelajaran semacam ini.

\section{KESIMPULAN}

Berdasarkan hasil informasi dan temuan yang telah penulis sajikan di atas, baik berasal dari data-data literatur yang terkait dengan penelitian ini, maupun data yang diperoleh dari hasil penelitian di lapangan melalui metode observasi, dokumentasi, serta wawancara yang kemudian dianalisis dengan menggunakan langkah-langkah teknik analisis data, akhirnya dapat disimpulkan hal-hal sebagai berikut:

Peran guru sangat penting dalam pembelajaran, karena belajar tidak bisa dipaksakan oleh orang lain dan tidak bisa dilimpahkan kepada orang lain, belajar adalah menyangkut apa yang harus dikerjakan siswa untuk dirinya sendiri. Maka inisiatif harus datang dari siswa sendiri, guru sekedar pembimbing dan pengarah, dengan kata lain tugas guru adalah membelajarkan siswa dengan menggunakan berbagai macam metode pembelajaran yang 
dapat membangkitkan keaktifan siswa dalam proses pembelajaran.

Siswa bukan saja dididik agar memiliki ilmu pengetahuan dan moral yang baik, tetapi juga agar mereka memiliki keterampilan (skill) yang sangat dibutuhkan dalam menghadapi tantangan hidupnya di masa depan. Guru berkewajiban memberikan pengalaman secara nyata kepada siswa dalam proses pembelajaran, salah satu metode yang memberikan kesempatan seluas-luasnya kepada siswa untuk aktif dalam proses pembelajaran sehingga mereka memiliki pengalaman yang lebih banyak adalah metode pembelajaran Role Playing.

Metode Role Playing yang diterapkan pada pembelajaran Fiqih di MTsN Rarangjami Indihiang Kota Tasikmalaya dapat meningkatkan aktivitas belajar siswa, proses pembelajaran cenderung telah berpusat pada siswa yang ditandai dengan peningkatan aktivitas belajar siswa, pada siklus I aktivitas belajar siswa secara klasikal sebesar $62 \%$ menjadi $82 \%$ pada siklus II.

Metode Role Playing yang diterapkan pada pembelajaran Fiqih di VIII A MTsN Rarangjami Indihiang Kota Tasikmalaya dapat meningkatkan hasil belajar/prestasi belajar siswa, ini terlihat dari peningkatan ketuntasan klasikal hasil tes akhir observasi awal ke siklus I yaitu dari $37,5 \%$ pada observasi awal, menjadi $72,5 \%$ pada siklus I dan dari siklus I ke siklus II yaitu dari 72,5\% pada siklus I menjadi 95\% pada siklus II.

\section{REFERENSI}

Arikunto, Suharsimi, Dasar-dasar Evaluasi Pendidikan, Jakarta: PT Bumi Aksara, 2002
Arikunto, Suharsimi, et.al, Penelitian Tindakan Kelas, Jakarta: Bumi Aksara, 2007

Dirjen Bagais, Standar Kompetensi Kurikulum $2004 \quad$ Madrasah Tsanawiyah, Jakarta: Depag RI, 2005

Echols, John M., dan Hassan Shadily, Kamus Inggris Indonesia, Jakarta: Gramedia, 2000

Hamalik, Oemar, Perencanaan Pengajaran Berdasarkan Pendekatan Sistem, Jakarta: Bumi Aksara, 2003

Hamalik, Oemar, Proses Belajar Mengajar, Jakarta: PT. Bumi Aksara, 2007

Ma'arif, Syamsul, Revitalisasi Pendidikan Islam, Yogyakarta: Graha Ilmu, 2007

Nurhadi dan Agus Gerrad Senduk, Pembelajaran Kontekstual (Contextual Teaching and Learning/CTL) dan Penerapannya, Malang: Penerbit Universitas Negeri Malang, 2003

Riyanto, Yatim, Metode Penelitian Tindakan, Surabaya: Penerbit SIC, 2001

Sudjana, Nana, Dasar-Dasar Proses Belajar Mengajar, Bandung: Sinar Baru Algesindo, 2005

Sujdjana, Nana dan Ibrahim, Penelitian Kualitatif dan Penelitian Kuantitatif, Bandung: Sinar Baru, 1989

Suryabrata, Sumadi, Psikologi Pendidikan, Jakarta: Raja Grafindo Persada, 1998

Tohirin, Psikologi Pembelajaran Pendidikan Agama Islam, Jakarta: Rajagrafindo Persada, 2006

Tu'u, Tulus, Peran Disiplin pada Perilaku dan Prestasi Peserta Didik, Jakarta: Grasindo, 2004

Undang-Undang No. 20 tahun 2003 tentang Sistem Pendidikana Nasional 